\title{
The empowerment strategy for prostitutes through competency- based culinary skills training at Semarang Rehabilitation Center
}

\author{
Sri Hartadi *, Fakhruddin Fakhruddin, Utsman Utsman \\ Department of Nonformal Education, Postgraduate, Universitas Negeri Semarang. \\ Gedung C Kampus Pascasarjana Jalan Kelud Utara III, Semarang 50237, Indonesia \\ *Corresponding Author. Email: srihartadi1993@gmail.com \\ Received: 21 February 2019; Revised: 26 February 2019; Accepted: 5 March 2019
}

\begin{abstract}
Prostitution is a phenomenon that has existed for a long time in the world, not least in Indonesia. Someone does prostitution most of the problem lies in economic factors and the low skills they have. The government does not remain silent due to this phenomenon, the government has also prepared a variety of skills training programs held in various rehabilitation institution, one of which is in the rehabilitation center of the Semarang city agriculture with empowerment programs through competency-based culinary skills training. The purpose of this study is to describe and analyze the planning, implementation, and results achieved in empowering prostitutes through competency-based culinary skills training. This study uses a qualitative approach. Data collection techniques are carried out by observation, interviews, and documentation. Data analysis techniques include data collection, data reduction, data presentation and conclusion drawing. Check the validity of the data using source triangulation and methods. The results of this study is planning of prostitutes empowerment programs through training in cookery skills includes: identification of needs, formulating learning objectives, determining curriculum to be used, choosing learning resources, and sources of funding. The implementation includes three main steps, namely opening activities, core activities, and closing. The results achieved are that the residents learned how to make steamed sponge, potato donuts, stuffed dumplings, banana chocolate roll omelet.

Keywords: empowerment strategy, culinary skills training
\end{abstract}

How to Cite: Hartadi, S., Fakhruddin, F., \& Utsman, U. (2019). The empowerment strategy for prostitutes through competency-based culinary skills training at Semarang Rehabilitation Center. JPPM (Jurnal Pendidikan dan Pemberdayaan Masyarakat), 6(1), 11-23. doi:https://doi.org/10.21831/jppm.v6i1.23697

d

https://doi.org/10.21831/jppm.v6i1.23697

\section{INTRODUCTION}

Prostitution is a phenomenon that has been there for a long time in the world, not least in Indonesia. The prostitution in Indonesia started from Javanese Kindom era which used women as a part of feudal system commodity. The prostitution phenomenon is still an unresolved problem. Prostitution or prostitution is a complex social problem, considering that prostitution is one of the oldest civilizations in the world and continues to exist in our society. The word "Prostitution" or can be interpreted by the word "Prostitution", since long ago people talked about. In Indonesia in talks or in writing in newspapers or magazines and the like, no one has discussed it broadly and objectively, but sometimes it is subjective in the form of reproach or self-criticism of prostitutes and often sensational for commercial purposes solely while certain groups view prostitutes as women who are immoral, cannot stand the faith and various anti-starch attitudes to "prostitutes" who, due to various things entering the dark world, do not pay attention to the relation to various aspects of people's lives that are associated with prostitution.

In terms of the several factors that cause someone to do a prostitution, most of the problems lie on economic and social factors. Economic factors are influenced by one's income or needs, whereas social factors 


\section{JPPM (Jurnal Pendidikan dan Pemberdayaan Masyarakat), 6 (1), 2019 - 12}

Sri Hartadi, Fakhruddin Fakhruddin, Utsman Utsman

are influenced by environmental conditions, environmental atmosphere and education of a person. So prostitution occurs due to lack of physical and spiritual well-being. "Inner-born well-being" is inseparable from aspects of human life or livelihood including security and peace that can be achieved if public awareness of the obligation to respect the rights of others has been understood and internalized so that law enforcement and justice are based on truth that has been fulfilled by others, needs of all members society. The difficulties to keep the needs for some women, who have lack of skills, will do the short action by peddling themselves in localization. According to Novrial (2004) as cited in Amaliyasari \& Puspitasari (2008) stated that the creation of Commercial Sex Workers (CSW) is generaly start from a compulsion regarding with family and personal problems, sexual violence trauma, and the difficulty to find a job in the middle of the life problems. Qayyum, et.al. (2013), concluded that in Pakistan, there are various factors and reasons of women's involvement in sex working. Those factors include social, economic, and political factors, and some hidden factors which encourage them to involve in prostitution. The inititions and decisions to become a prostitute, some of them join it voluntarily and others are accidentally. Voluntarily, the women who are included in sexual working, it is because some natural and artificial situations such as the lack of economic resources, family diseases, lack of education, poverty, debt burden, sex pleasure, peer relations, family neglect, household clashing, husband's drugs addiction, and some others.

The government does not keep quite to this phenomenon. They will make sure that Indonesia is clear from prostitution in 2019. However, in line with the existence of the policy, the government has also prepared a variety of skills training programs which are held in rehabilitation homes, one of which is in Agrorejo Semarang resocialization/rehabilitation center. One of the programs which is held in that institution is the empowerment of prostitutes through culinary skills training programs for them so they are no longer work within the scope of prostitution and being self-employed. Empowerment can be done through three levels of empowerment settings: (1) micro level, empowerment is carried out on individual subjects through guidance, counseling, stress management, crisis inventory. The main goal is to guide or train the learning population in carrying out their life's tasks. This model is often referred to as task centered approach. (2) the level of mezzo, empowerment is carried out on a group of learning citizens. Empowerment is done by using groups as a medium of intervention. Education and training, group dynamics, are usually carried out as a strategy in increasing the awareness, knowledge, skills and attitudes of the learning community so that they have the ability to solve the problems they face. (3) Macro level, this approach is also called a large-system strategy, because the target of change is directed to a broader environmental system. Policy formulation, social planning, campaigning, social action, lobbying, community organizing, conflict management, are some of the strategies in this approach. Large system strategies see citizens learning as people who have the competence to understand their own situations, and to choose and determine the right strategy for action.

The research conducted by Agnihotri HR., \& Malipatil (2017) concluded that women empowerment is making them independent in all aspects of thoughts, rights, decisions, etc. by leaving the all social and family imitations. This is to bring the equality in society for both the men and women in all fields. The women empowerment is needed to make the future of the family, society, and bright country. Widjajanti (2011), the main goal of society empowerment is those who are weak and helpless, or marginalized people in the development. The ultimate goal of the society empowerment process is to empower the community so they can improve their family standard of living and optimize their resources. The findings of Brahmana, Brahmana, \& Ho (2018) stated that: "Quality human resources have an impact on organizational performance, as the cor of an organization".

In improving the human resources quality can be done through training, as 


\section{JPPM (Jurnal Pendidikan dan Pemberdayaan Masyarakat), 6 (1), 2019 - 13}

Sri Hartadi, Fakhruddin Fakhruddin, Utsman Utsman

according to Millan (1984) as cited in (Bibi, Ahmad, \& Majid 2018) which stated that: "Training and developmentis a human resource management practice that helps organizations to gain a competitive edge".

Santosa (2014), clarified that empowering the villagers can be understood as an improvement of autonomus capacity utilization process of each individual to use local resources productively and creatively in a rural society. Every society development efforts which are based on local resources need to be oriented to support the importance of poverty alleviation in various typologies of rural area. The empowerment and training are the part of non-formal education. Empowerment process is generally carried out collectively. There is no literature which state that empowerment process occurred in one-to-one relationship between instructors and learning citizens in individual help setting. Although this empowerment can increase self-confidence and self-ability of learning citizens, this is not the main empowerment strategy. In some situation, the empowerment strategy can be done individually, although in its turn, it is still related to the collectivities which mean it relates the learning citizens and the sources or another system outside themselves. This is supported by the result of the study of Johnson (2015) which stated that vocational training program plays a key role in empowering rural women. The researcher concludes that poor women looked positive towards the income generation program. Karwati (2017), concluded that empowerment is an effort to make something fair and civilized become more effective in all aspects of life. Women empowerment is needed to improve their skills and life skills so that they can be empowered and are able to use their potential. The research results showed that the ability to obtain the educational skills is able to make entrepreneurial opportunities in imporving their quality of life and affecting women's independence at the better socioeconomic level, through empowermentbased entrepreneurship in which the women can play a role in public life especially to help them repair the family status and needs. Sultana (2013), concluded that the role of women is very important for the economic growth. The women's involvement in income related activities increase the empowerment level. An empowered woman can use her power on her own choice in making household decisions; contributing towards the household income, and controlling resources and political or developmental activities. While the research by Kurniawati (2013) stated that supporting factor for the implementation of women empowering in the productive economic business field is the role of Community Empowerment Agencyas as coordinator and facilitator.

The term training is a translation of the word "training" in English. Literally the root word "training" is "train", which means: (1) giving lessons and practice (give teaching and practice), (2) making it develop in the direction that is needed (cause to grow a required direction), (3) preparation, and (4) practice (practice). Then training can be interpreted as a process to develop skills, knowledge, disseminate information and update behavior and help individuals or groups in an organization to be more effective and efficient in carrying out their main tasks and functions in work. The training activities are oriented to increase the potential of participants to be able to improve the better quality of life for all citizens through self-help activities. To achieve this goal, the factor of improving the quality of human resources through formal and non-formal education needs to be prioritized. Training activities aim to educate the public to be able to educate themselves "or" help the community to be able to help themselves". The goal will be achieved through training, which is an independent, self-reliant society, capable of adopting innovation, and having a cosmopolitan mindset. This is supported by the result of the study by Alfiah (2013) who stated that sewing life skill training have to appears in learning citizens attitude and character changes, have quality assets to behave, and ready to face the career development, so they are able to choose, enter, compete, and go forward in work world, they are able to survive in their independence, and learn without guidance, they have a degree of independence, openness, cooperation, and 


\section{JPPM (Jurnal Pendidikan dan Pemberdayaan Masyarakat), 6 (1), 2019 - 14}

Sri Hartadi, Fakhruddin Fakhruddin, Utsman Utsman

accountability which become their mental attitude so they live happily in the middle of the time. Winarti (2017), concluded that the implementation of rural entrepreneurship training which is oriented towards women empowerment has an increased awareness of independent businesses and group busnisses which have various new dishes from local raw materials.

According to Moekijat as cited in Sutarto (2013), in general, the training aims to: (a) increase the expertise, so the work can be more quickly and effectively completed, (b) develop the knowledge, so the work can be rationally finished, and (c) develop the attitudes, thus it raises willingness to cooperate. Usually the level of knowledge from the results of the training that he has participated in can reflect a person's intellectual abilities. Although traditionally the type and level of education a person uses to find work as a measure to assess the ability of job applicants. In fact, it is not impossible for someone who has high intellectual abilities, for example due to economic disability or due to other factors. Therefore training is still considered more effective in efforts to help the development of human resources.

In accordance with the government policy that Indonesia is free of prostitution in 2019, so in this training, learning citizens are trained in skills training for being an entrepreneur which focus on culinary skill training. With any type and variety of characteristics, in the end the training needs to be managed. Proper and professional management of training can provide functional meaning to training for individuals, organizations and communities. (Kamil 2012, p. 16; Sudjana, 2003) develops ten steps of training management as follows: (1) recruitment of training participants, (2) identification of learning needs, learning resources, and possible obstacles, (3) determining and formulating training objectives, (4) compiling initial evaluation and final evaluation tools, (5) compiling a sequence of training activities, (6) training for trainers, (7) carrying out evaluations for participants, (8) implementing training, (9) final evaluation, (10) evaluating training programs. Empowerment and training are part of non-formal education which has various legal bases to be delivered as follows: Law of the Republic of Indonesia No. 11 of 2009 concerning social welfare article 1 paragraph (2), which states that: The Implementation of Social Welfare is a directed, integrated and sustainable effort carried out by the government, regional government, and society in the form of social services to meet the basic needs of every citizen, which includes social rehabilitation, social security, social empowerment, and social protection. And in paragraph (10), states that: social empowerment is all efforts directed at making citizens who experience social problems have the power, so they are able to fulfill their basic needs. Still in the laws of the Republic of Indonesia No. 11 of 2009 Article 12, which states that: paragraph (1) Social empowerment is intended to: (a) empower someone, family, group, and community who experience social welfare problems in order to be able to meet their needs independently. (b) increasing the participation of institutions and/or individuals as potential and resources in the implementation of social welfare. Paragraph (2) The social empowerment as referred to in paragraph (1) is carried out through: (a) an increase in willingness and ability; (b) extracting potential and resources; (c) extracting basic values; (d) granting access; and/or (e) providing business assistance. Paragraph (3) social empowerment as referred to in paragraph (1) letter (a) is carried out in the form of: (a) diagnosis and motivation; (b) skills training; (c) assistance; (d) providing capital stimulants, business equipment, and place of business; (e) increasing access to marketing of business products; (f) supervision and social advocacy; (g) reinforcement social harmony; (h) environmental management; and/or (i) advanced guidance. Paragraph (4) Social empowerment as referred to in paragraph (1) letter (b) is carried out in the form of: (a) diagnosis and motivation; (b) strengthening community institutions; (c) partnerships and fundraising; and/or (d) administration of stimulants. National education system law No. Article 20 states that: (1) Non-formal education is held for citizens who need educational services that function as substitutes, enhancers, and/or complemen- 
tary formal education in order to support lifelong education, (2) Non-formal education functions to develop potential participants students with an emphasis on mastering knowledge and functional skills as well as developing professional attitudes and personalities, (3) Non-formal education includes life skills education, early childhood education, youth education, women's empowerment education, literacy education, skills education and job training, equality education, and other education aimed at developing students' abilities, (4) Non-formal education units consist of course institutions, training institutions, study groups, community learning centers, and taklim assemblies, and similar education units, (5) Courses and training tihan is held for people who need knowledge, skills, life skills, and attitudes to develop themselves, develop their profession, work, independent business, and/or continue their education to a higher level, (6) Nonformal education results can be valued equivalent to results formal education program after going through an equalization assessment process by an institution appointed by the Government or regional government with reference to national education standards, (7) Provisions regarding the implementation of non-formal education as referred to in paragraph (1), paragraph (2), paragraph (3), paragraph (4), paragraph (5), and paragraph (6) are further regulated by government regulations.

Government Regulation No. 17 of 2010 concerning education management and implementation article 113 which reads: (1) Skills education and job training are intended for job seekers or those who have worked, (2) Skills education and job training as referred to in paragraph (1) are implemented for: (a) increase motivation and work ethic; (b) develop a personality that matches the type of work of students; (c) increase insight into environmental aspects that are in accordance with work requirements; (d) improve the ability of functional skills in accordance with the demands and needs of work; (e) improve the ability to build social networks in accordance with the demands of the work; and (f) improve other capabilities in accordance with the demands of the work, (3) The ability of functional skills as referred to in paragraph (1) includes: vocational skills, managerial skills, communication skills, and/or social skills. (4) Skills education and job training can be implemented in an integrated manner with: (a) life skills education programs; (b) education program equality in Package $B$ and Package C; (c). women's empowerment education program; and/or (d) youth education programs (Presiden Republik Indonesia, 2010).

In achieving those goals, it is needed a strategy that can support the objectives achievement process which have been decided. Looking at the above description, this research will examine the Empowerment Strategy for Prostitution through Compentency-Based Cullinary Skills Training in Semarang Rehabilitation Institution.

\section{METHOD}

The success of the activities carried out in a lot of research is determined by whether or not the research method used The accuracy in choosing a method will govern the direction and purpose of the research. Therefore research methods have an important role in determining the quality of research results. In this research method, there are several things that can determine the steps for carrying out research activities. This is so that the research activities run systematically. The steps that must be determined in this study are the research approach, research location, research subject, research focus, data sources, data collection techniques, data validity, and data analysis techniques.

The approach used in this study was qualitative approach. According to Bungin (2007, p. 68) social research which used descriptive qualitative format aimed to describe, summarize various condition and situation, or various phenomena of social reality existed in society which were the oject of this study,and tried to attract those realities as identity,character, attitude,model, sign, or the description of a certain conditions, situations, or phenomena. By this descriptive qualitative method which described the existing phenomena, there would be obtained an understanding of the inter- 


\section{JPPM (Jurnal Pendidikan dan Pemberdayaan Masyarakat), 6 (1), 2019 - 16}

Sri Hartadi, Fakhruddin Fakhruddin, Utsman Utsman

pretation and reality and in depth about the meaning of reality and facts, because the problems of this study did not use the numbers but this would describe, elaborate, illustrate the implementation of learning model and the participants' work readiness after completing the training.

The determination of the data sources to the interviewed people in this study was carried out purposively. Puprosive was that the sample (informant) was chosen by certain considerations and objectives. Those were intended to determine and choose the informant who was considered know the most about the social situation studied. According to Lofland and Lofland (1984) in Moleong (2014, p. 157), mentioning that "the main data source in qualitative research is words, and actions, the rest are additional data such as documents and others". The data sources in this study are in the form of information and documents. Data sources were obtained from key informants and other informants. Informants are those who are interviewed by researchers so that they can provide information and information. The selected informants are people who really know or are directly involved with the focus of the problem, so that researchers can summarize important information in accordance with the focus of the study. The key informants in this research were the people who had a strategic position and understood about the prostitute empowerment through culliary skills training such as the head of rehabilitation institution and the instructors. Through the key informants, their advice and support could be asked for the access to another evidence sources which supported the research focus. That access could be obtained in the form of information from the learning citizens.

The source of data in this study was primary data which was obtained by the head of rehabilitation institution, instructors, and learning citizens. The secondary data was the additional data which was used to complete the data. Secondary data sources are sources that do not directly provide data to data collectors, for example through other people or through documents, Sugiyono (2013, pp. 308-309). So secondary data comes from the second, third, and so on. This means passing one or more parties who are not researchers. Secondary data sources in this study are documents, records, notes, or photographs and other materials related to this research. That was obtained by documentation or literature which was carried out by examining scientific books related to the empowerment strategy and skills training. The data collection techniques used was observation, interview, and documentation. Observation method is a method of collecting data using observation techniques that are based on direct observation by observing themselves and experiencing the events directly (Moleong, 2014, p. 174). The researcher made observations directly in the field by making selective notes to observe all matters related to research problems and which were considered important. The object of observation includes learning people, amounting to 20 people, the state of the environment, facilities such as cooking tools and other supporting equipment, learning methods, curriculums that are used, the time of learning is carried out 2 (two) weeks, on Tuesday, where training is held in rehabilitation halls, product results from training and learning behavior of students during the implementation of learning in the argorejo institution in Semarang. The interview method is a method of collecting data by way of interviews, namely getting information by asking questions directly to the respondents. The interview that will be used in this study is an unstructured interview where the interviewer determines his own problems and questions to be asked, not the same for all subjects (Bungin, 2007). Therefore, what is meant by interviews in this study is conversations conducted by two parties, namely the interviewer who asks the question and the interviewee who answers the question by using an unstructured interview where the interviewer establishes the problem himself but the question to be asked is not the same for all subjects. In this interview method, the researcher conducted an interview with the chairman of the Semarang city argorejo nursing home, training tutor and study community to get maximum results in this study. The reason for using interview tech- 
niques is expected to facilitate and examine more deeply related to the focus of the research. Interviews are conducted using structured interviews with the hope of being able to direct the honesty of every thought when providing information. Documentation method is a method for obtaining data through searching data or documents regarding matters in the form of notes, transcripts, books, agendas, schedules, photos and so on. This method is not very difficult to use, in the sense that if there is a mistake the data source is still fixed, it has not changed. The documentation method observed is not a living thing but an inanimate object. (Arikunto, 2002). Therefore, what is meant by documentation in this study is the method of collecting data by searching data or documents regarding matters in the form of notes, transcripts, books, agendas, schedules, photos and so on. Documentation is intended to uncover less data from interviews and observations as proof of research. Documentation can be in the form of photos relating to research, using written relics in the form of archives, books, newspapers, magazines or other agendas related to the activities under study.

The validity of the data used in this research was data/source triangulation and method triangulation. The researcher used source triangulation which compared and checked both trust degree of the information obtained by using the guidelines that have been arranged and prepared for collecting data. Triangulation methods used were interview, observation, and documentation. The data analysis used in this research took place in data collecting process. The analysis included three ways of activities; they were data reduction, data presentation, and conclusion. The purpose of data analysis is to simplify data into forms that are easier to read and interpret. After the data is collected, the next is data analysis. This study uses qualitative analysis, including interview notes, observation notes relating to the problem under study, and official data in the form of documents or archives. The main steps in interactive analysis are: Data collection. Data collection is defined as a process of collecting data through interviews, observation, and documentation to get complete data. Data Reduction is a selection process, focusing rough data abstraction, and simplifying data by leaving things that are not important. Data Presentation, ie researchers assemble the organization of data obtained so that the researcher allows to draw conclusions by paying attention to the data present.

\section{RESULTS AND DISCUSSION}

The empowerment strategies which were implemented in culinary skills training included: planning, emplementaion, and achievement results.

\section{The Prostitutes Empowerment Planning through Culinary Skills Training}

The empowerment planning was extremely needed as an initial step in establishing the empowerment implementation guidelines. Therefore, the instructors must be able to design or plan and prepare the steps which would be carried out during the training so the objectives of it could be achieved effectively and efficiently. According to the theory of Sudjana (2003) as cited in Sutarto (2013) the prostitutes empowerment through compentency-based culinary skills training in Semarang Rehabilition Intitution, there were 5 (five) components which must be carried out in training planning process. Those components were (1) the identification of needs, (2) the goals, (3) the curriculum, (4) the learning sources, and (5) funding sources.

The first was needs identification. Based on the research results, the results of the identification became the basis to carry out appropriate training for prostitutes. If there were learning citizens who like cooking, they were directed to culinary, as well as for other training. The identification process involved all training instructors. Economic problems are still a fundamental problem so that individuals who are less able to meet their economic needs will do everything to achieve the expected needs, one of which is to become a prostitute. The education level of the learning citizens were secondary school. In the training, learning citizens did not only participate once, but they participated in it continously. The results of the study were in line with the research from Saugi and 
JPPM (Jurnal Pendidikan dan Pemberdayaan Masyarakat), 6 (1), 2019 - 18

Sri Hartadi, Fakhruddin Fakhruddin, Utsman Utsman

Sumarno (2015, pp. 226-238) which concluded that participatory planning consisted of identifying needs and preparing the program management team.

The second was formulation of purposes. Based on the research results of empowerment through culinary skills training, it aimed to equip prostitutes to have some skills in culinary which later will increase their economy or cost of living through business or working in the field of cooking. The results of this research were in line with the objectives of empowerment according to Najiyati, Asmana, \& Suryadiputra (2005, p. 115), they are as follows: (a) Developing authentic and integral human beings from weak, poor, marginal, and small people such as farmers, farm laborers, poor societies, disabled and group of women who are discriminated against or excluded. (b) Empowering those community groups through socio-economic conditions so that they can be more independent and can fulfill their basic needs of life and can participate in community development as well.

The third was curriculum determination. Based on the research results, the curriculum used was a competency-based curriculum. These competencies were directed at mastering the making of various cakes and dishes that can be innovated. The results of the study were in line with Sudjana (2003) in Sutarto (2013), it explained that the curriculum is a collection of experiences and ideas arranged in the form of activities as a learning process in such a way that experiences and ideas are interwoven, presented with methods and data that are appropriate with the needs by paying attention to existing values.

The fourth was determination of learning sources. Based on the research results, the learning sources used in empowering skills in competency-based culinary training came from the modules and the instructors. The results of the research were in lie with the research from Wardani (2013, pp.56-6o), stating that learning sources are taken from human learning sources, they are tutors with characteristics of having work experience for 8-10 years in the metal industry.
The fifth was determination of funding sources. Based on the research results, fund sources were obtained to conduct programs in rehabilitation home, one of which was prostitute empowerment through competency-based culinary skills training from Social Agency.

\section{Implementation of Prostitutes Empowerment through Culinary Skills Training}

Implementation is main process in conducting a program. In the implementation activities, it needs sistematics stages so that the implementation can be run effectively and efficiently. From the research results done by the researcher, the training implementation of culinary at social rehabilitation home in Agrorejo was mostly done through three activities. They were opening, materials delivery, and closing. These results were in line with the research done by Ernawati \& Mulyono (2017), stating that there are three stages in learning, they are opening activity before conducting learning, main activity (materials delivery), and closing activity (activity to end the lesson).

The first was opening activity. Opening activity and introduction is an integral part which cannot be separated from other activities. In other word, opening activity is done to prepare mental and attention from learning citizens so that they can focus on things they learn. This activity was preliminary activity of learning aiming to prepare learning citizens to be ready to accept the learning materials. Based on the research results, opening activity in prostitutes empowerment through culinary skills training was praying activity directly leaded by the instructors. The praying was done in order to have the learning process run well. The next activity done by the instructors were asking the condition to the learning citizens. This activity is important to do by the instructors when he/she enters the class because it can strengthen the relationship between instructors and learning citizens. The research results were supported by the research from Sumiah \& Khosmas (2013), stating that opening learning skills can increase students learning outcomes because it can make them 


\section{JPPM (Jurnal Pendidikan dan Pemberdayaan Masyarakat), 6 (1), 2019 - 19}

Sri Hartadi, Fakhruddin Fakhruddin, Utsman Utsman

focus on materials served so that they will understand them more easily. Next, check or check the attendance of participants. Because with these activities, the instructor can get to know all the participants and bridge the instructor to attract the attention of the participants so that participants can devote their attention to the learning that will be carried out. These results are relevant to the learning steps of the theory information processing model from (Joyce \& Weil, 2011), that the first step in learning is to take action to attract students' attention. No less important activities with other activities at the opening are creating a conducive learning climate, the conducive climate that occurs in the learning process will form a strong nonformal education unit, where the strength of the climate created can influence the intensity of the learning behavior in implementing learning (Sutarto, 2013). Based on the results of the study, the learning climate created in empowering WTS through culinary skills training includes classrooms far from the crowds, adequate room lighting, the presence of pickets, besides that it is also supported by sufficient practical equipment. The findings of the researchers are supported by the results of research from (Carrim \& Basson, 2013) that:

"The study revealed that a learning climate can be created in different types of organizations through organizational, group and individual drivers. It further revealed that the strategy in creating a climate of learning should be aligned with the organization's structure, culture and goals".

The second was main activity. The main activity is the presentation of material using learning model, learning method, learning media, and learning resources that are adjusted to the characteristics of students and subjects (Fauziah, Abdullah, \& Hakim, 2017). The main activity was the activity of presenting learning material. Presentation of learning material is one effort to achieve the objectives of the training program that has been set. The empowerment program organized by social rehabilitation institution in Agrorejo through culinary skills training for prostitutes is an empowerment program that has been implemented since the beginning of 2018. This culinary skills training was the second period, in which the training was held in just 6 days starting on 22-29 October 2018. The implementation of culinary skills training lessons was conducted on Monday to Saturday, starting at 8:00 a.m. to 1:0o p.m. in the rehabilitation institution hall. The number of active members in the rehabilitation institution is 460 people, but only 50 people attended the culinary skills training. The number of those attending the training was not comparable to the number of active members in the rehabilitation institution. It happened because the training organize did not obligate learning citizens to take part in the culinary skills training. The instructor was the education staff on duty and functions to carry out education and training. There were two instructors in catering training, of which the two instructors have different educational backgrounds. They were Bachelor degre and Vocational School graduate majoring in culinary. The learning method is a method used by the instructor to convey the material taught to the learning population in the learning process. In delivering material the instructor used lecture learning methods, practices, questions and answers and demonstrations where the use of those methods were adjusted to the needs or situations that exist. The results of the study were supported by the theory of (Nurhalim, 2011, p. 83) stating that the learning methods commonly used in learning include exercises, lectures, and question and answer methods. The material is learning material that is delivered/presented to learning citizens during the learning process. Based on the results of the research that were obtained from the material given to the learning citizens about the ingredients of the recipe and how to make steamed sponge cake, potato donuts, boiled rice cake, chocolate roll omelet filled with gold banana. The instructors implemented the material in learning with a proportion of $25 \%$ for theory and $75 \%$ for practice. According to Triyanto (2013), the learning process is a communication process and takes place in a system so that the learning media occupies a fairly important position as one component of 
learning. Without media, communication will not happen and the learning process as a communication process will not be able to run optimally. Learning media is a tool used in the learning methods and techniques implementation. Learning media that will be used were up to the instructors because they understood more what media was suitable to use in learning. The media used by instructors in delivering material included whiteboards, markers, equipment for practice, LCD and supported by modules that contain prescription material from four menus. The results of this study are relevant to the theory of (Sutarto, 2013) that there are several benefits to using the media in the implementation of learning, including the implementation of learning will attract the attention of students, allowing the occurrence of more concrete and not verbalistic learning variations, material delivered by educators it will be easily understood by students, and learning media can overcome the limitations of the senses, space, and time.

The instructors used citizens learningcentered in implementing the learning. By using this approach, it could support learning so that it ran effectively. The results of this research were relevant to the theory of (Sanjaya, 2006, p. 30), one of the principles that must be considered in managing learning activities is student-centered. So, not only the instructors were active, but learning citizens were also required to actively participate in learning. These findings were supported by the results of research (Antika, 2014), stating that educators believe that the learning will run optimally if students are actively involved in the learning process. The research conducted by (Buditama, 2017) obtained results the student-centered teaching guide can enhanced the students' writing skill in the basic grammar. The way done by the instructor so that learning citizens were active was by the giving the opportunity to the learning citizens to ask questions or express opinions. The results of the above research are relevant to the theory of (Sunhaji, 2013), which states that one of the principles of adult learning is active learning, this principle requires participants to be diligent in learning if they are actively involved in the training process, as John said Dewy Learning by doing. Another theory that supports the results of this study is the theory of (Dimyanti \& Mudjiono, 2009), that the principle in learning is one of which is activeness, teaching is the process of guiding learning experiences. In learning activities the instructor fosters the motivation to learn the learning community. The results of the study (Omar, Jain, \& Noordin, 2013) state that "motivation can be defined as the process of a goal-directed activity". Motivation is very important in teaching and learning activities, because the motivation motivates learning and on the contrary lack of motivation will weaken the spirit of learning. Based on the results of the study, the instructor provides motivation to the learning community before learning begins and during the learning activities takes place. The motivation is given by the instructor giving an overview of entrepreneurs who have been successful in the field of entrepreneurship and giving enthusiasm to the learning community so that they seriously participate in training so that after they finish training they can become entrepreneurs to improve their standard of living. The results of this study are supported by the existence of research from (Waluyo \& Desmawati, 2015), which states that motivation is a factor that is quite important in influencing learning outcomes. Through the andragogy approach can increase the motivation of students in completing existing tasks. Then reinforced the results of research from (Sudarma \& Sakdiyah, 2007), the results of his research indicate that there is a positive influence between motivation on student achievement. Based on the results of the study, the obstacles in the implementation of culinary skills training were practice tools which were limited in number. This problem was handled by the instructor by forming groups during practical activities. The second obstacle was the allocation of time which was only 6 days. This made the implementation of learning less than optimal because the time was too short. Factors that support the implementation of prostitutes empowerment through culinary skills training were the enthusiasm of learning citizens in participating in the 
JPPM (Jurnal Pendidikan dan Pemberdayaan Masyarakat), 6 (1), 2019 - 21

Sri Hartadi, Fakhruddin Fakhruddin, Utsman Utsman

activity. The assessment carried out by the instructors after completion of learning was by giving questions to the learning citizens. From the answers of the learning citizens, it can be seen whether the learning citizens have really understands the materias have been delivered or not. For practice assignment, the main things assessed were group cohesiveness and the taste of the food they made.

The third was closing activities. The closing activity of a learning is as important as opening activity. The closing activity carried out by the instructors was to review whether the learning citizens had questions or not, this is done in an effort to determine the extent to which the learning community has understood the material provided by the instructor. If there were no learning citizens asking, the instructor closed the training activity by giving a closing greeting. The results of this study were supported by the results of research from (Paloloang, 2014), which stated that on the closing activity, the steps applied were to review the materials that have been delivered by guiding students to draw conclusions ande then close the learning by greeting and ask students to pray together.

\section{Achievement Results of Prostitutes Empowerment through Culinary Skills Training}

Based on the research results, the achievement results or evaluation of the learning citizens were done based on the understanding in direct practicing and group cohesiveness. The evaluation also considered the aspects of quality, and taste of food, while the achievement of the evaluation results has reached the predetermined target. Empowerment through competency-based culinary skills training is felt to be able increase experience and skills in cooking with innovation according to market conditions. The results above were in line with the results of research conducted by Saugi and Sumarno (2015, pp. 226-238) which stated that the success indicators of a training are the increase of knowledge and skills of people, and people obtain income from the sale of products.

\section{SUGGESTIONS}

Based on the research results and conclusions that have been described, the suggestion for the institutions of rehabilitation in Agrorejo, Semarang is that to complete the equipment for practice whose numbers are still limited so that it will not hinder the learning. For instructors, they need to prepare more systematic learning to see the characteristics of varied learning citizens and very limited time of implementation. For the learning citizens, they have to take learning seriously and enthusiastically so that they can receive the materials well and can practice recipes that have been learned.

\section{REFERENCES}

Agnihotri HR, R, R., \& Malipatil, K.S. (2017). A study on women empowerment schemes in India. International Journal of Development Research 7(8), 1430114308. Retrived from https://www.journalijdr.com/studywomen-empowerment-schemes-india

Alfiah, L. (2013). Pelatihan life skill menjahit dalam upaya meningkatkan kemandirian peserta didik kesetaraan paket C di PKBM Al-Hikmah Sukodono Sidoarjo. J+ PLUS UNESA, 2(2). Retrived from https://jurnalmahasiswa.unesa.ac.id/in dex.php/jurnal-pendidikan-luarsekolah/article/view/4425

Amaliyasari, Y., \& Puspitasari, N. (2008). Perilaku seksual anak usia pra remaja di sekitar lokalisasi dan faktor yang mempengaruhi. Jurnal Penelitian Dinas Sosial, 7(1), 54-6o.

Antika, R. R. (2014). Proses pembelajaran berbasis student centered learning (Studi deskriptif di sekolah menengah pertama Islam Baitul 'Izzah, Nganjuk). Jurnal biokultur, 3(1), 251-265.

Arikunto, S. (2002). Prosedur suatu penelitian: pendekatan praktek. Jakarta: Rineka Cipta.

Bibi, P., Ahmad, A., \& Majid, A. H. A. (2018). The impact of training and development and supervisor support on employees retention in academic 
JPPM (Jurnal Pendidikan dan Pemberdayaan Masyarakat), 6 (1), 2019 - 22

Sri Hartadi, Fakhruddin Fakhruddin, Utsman Utsman

institutions: The moderating role of work environment. Gadjah Mada International Journal of Business, 2o(1), 113.

https://doi.org/10.22146/gamaijb.24020

Buditama, M. (2017). Student-centered learning approach in teaching basic grammar. Journal on English as a Foreign Language, 7(2), 209-226.

Brahmana, R. K., Brahmana, R. K., \& Ho, T. C. F. (2018). Training and development policy, corporate governance, and firm performance. Gadjah Mada International Journal of Business, 20(1), 59.

https://doi.org/10.22146/gamaijb.12995

Bungin, B. (2007). Penelitian kualitatif: komunikasi, ekonomi, kebijakan publik, dan ilmu sosial lainnya. Jakarta: Kencana.

Carrim, N. M. H., \& Basson, J. S. (2013). Creating a learning climate: a South African study. The Learning Organization, 20(1), 6-19.

Dimyanti, D., \& Mudjiono, M. (2009). Hasil belajar dan pembelajaran. Jakarta: PT Rineka Cipta.

Ernawati, E., \& Mulyono, S. E. (2017). Manajemen pembelajaran program paket C di PKBM Bangkit Kota Semarang. Journal of Nonformal Education, $\quad 3(1)$, 60-71. https://doi.org/10.15294/jne.v3i1.8915

Fauziah, R., Abdullah, A. G., \& Hakim, D. L. (2013). Pembelajaran saintifik elektronika dasar berorientasi pembelajaran berbasis masalah. Innovation of Vocational Technology Education, 9(2). http://dx.doi.org/10.17509/invotec.v9i2. 4878

Johnson, E. J. (2015). Empowerment of women through Vocational Training. Basic Research Journal of education Research and Review, 4(2), 37-44.

Joyce, B., \& Weil, M. (2011). Models ofteaching (Model-model pengajaran). Terjemahan oleh Ahmad Fawaid \& Ateilla Mirza. Yogyakarta: Pustaka Pelajar.
Kamil, M. (2012). Education and Training Models: Concepts and Applications. Bandung: Alfabeta

Karwati, L. (2017). Pemberdayaan perempuan melalui pelatihan kewirausahaan berbasis potensi alam setempat. Jurnal Ilmiah Visi, 12(1), 45-52. https://doi.org/10.21009/JIV.1201.5

Kurniawati, D. P. (2013). Pemberdayaan masyarakat di bidang usaha ekonomi (Studi pada Badan Pemberdayaan Masyarakat Kota Mojokerto). Jurnal Administrasi Publik, 1(4), 9-14.

Moleong, L. (2014). Qualitative research methodology. Bandung: Remaja Rosdakarya.

Najiyati, S., Asmana, A., \& Suryadiputra, I. N. N. (2005). Pemberdayaan masyarakat di lahan gambut. Bogor: Wetlands International - Indonesia Programme.

Nurhalim, K. (2011). Strategi pembelajaran pendidikan nonformal. Semarang: Universitas Negeri Semarang.

Omar, S., Jain, J., \& Noordin, F. (2013). Motivation in learning and happiness among the low science achievers of a Polytechnic Institution: An exploratory study. Procedia-Social and Behavioral Sciences, 90, 702-711.

Paloloang, M. F. B. (2014). Penerapan model problem based learning (PBL) untuk meningkatkan hasil belajar siswa pada materi panjang garis singgung persekutuan dua lingkaran di kelas VIII SMP Negeri 19 Palu. Jurnal Elektronik Pendidikan Matematika Tadulako, 2(1).

Presiden Republik Indonesia. Peraturan Pemerintah Republik Indonesia nomor 17 tahun 2010 tentang pengelolaan dan penyelenggaraan pendidikan (2010).

Presiden Republik Indonesia. UndangUndang Republik Indonesia nomor 20 tahun 2003 tentang sistem pendidikan nasional, Pub. L. No. 20, UndangUndang Republik Indonesia 26 (2003). Indonesia.

Qayyum, S., Iqbal, M. M. A., Akhtar, A., Hayat, A., Janjua, I. M., \& Tabassum, S. (2013). Causes and Decision of Women's 
JPPM (Jurnal Pendidikan dan Pemberdayaan Masyarakat), 6 (1), 2019 - 23

Sri Hartadi, Fakhruddin Fakhruddin, Utsman Utsman

Involvement into Prostitution and its Consequences in Punjab, Pakistan. Academic Research International, 4(5), 398.

Sanjaya, W. (2006). Strategi pembelajaran berorientasi standar proses pendidikan. Jakarta: Kencana Prenada Media Group.

Santosa, I. (2014). Strategic management of rural community empowerment: based local resources. In 2014 International Conference on Public Management. Atlantis Press.

Saugi, W., \& Sumarno, S. (2015). Pemberdayaan perempuan melalui pelatihan pengolahan bahan pangan lokal. JPPM (Jurnal Pendidikan dan Pemberdayaan Masyarakat), 2(2), 226 238.

doi:https://doi.org/10.21831/jppm.v2i2.6 361

Sudarma, K., \& Sakdiyah, E. M. (2007). Pengaruh motivasi, disiplin, dan partisipasi siswa dalam pembelajaran terhadap prestasi belajar akuntansi. Dinamika Pendidikan, 2(2).

Sudjana, D. (2003). Pendidikan luar sekolah, wawasan, sejarah perkembangan filsafah dan teori pendukung azas. Bandung: Nusantara Press

Sugiyono, S. (2013). Metode penelitian manajemen. Bandung: Alfabeta.

Sumiah, N., \& Khosmas, F. Y. (2013). Analisis keterampilan mengajar guru dalam meningkatkan hasil belajar pada mata pelajaran ekonomi di SMA. Jurnal Pendidikan dan Pembelajaran, 2(9).

Sunhaji, S. (2013). Konsep pendidikan orang dewasa. Jurnal Kependidikan, 1(1), 1-11. https://doi.org/10.2409o/jk.vii1.528

Sutarto, J. (2013). Manajemen pelatihan. Yogyakarta: Deepublish. 